\title{
GLOBAL ISLAMIC FINANCE ASSETS: ANALYSIS OF THE ISLAMIC BANKING IN ALGERIA
}

\author{
Sissani Midoun \\ University Ibn Khaldoun ,Tiaret,Algeria \\ sissanim@gmail.com \\ Tagrerout Med \\ University Hassiba Ben Bou Ali Chelf \\ tagmouh2@yahoo.fr
}

\begin{abstract}
No doubt that Islamic banks have proved its efficiency and effectiveness in both :In methods of financial management and also in the mobilization of financial resources for the sake to promote development in various economic sectors not only in Islamic countries but even in European as well and of course according to Islamic Sharia rules. The aim of this paper is to examine the performances and the Islamic methods adopted to improve the allocation of financial resources and its specific ways to boost earnings. Besides, Islamic financial assets were involved in huge financial markets due to its high quality of financial services provided to investors. Actually, Islamic banking exists in more than 67 countries and by the end of 2019 they may reach about 75 countries in the world. The results show that legislation, shortage of qualified individuals and the lack of using a high technology are the most critical factor of Islamic banking in Algeria.
\end{abstract}

Keywords: Islamic Banking; Islamic assets; Usury; Islamic Sukuk; Business ethics

\section{JEL Classification}

E44; G10; G21

\section{Introduction}

Rising trends of Islamic finance has increased since its establishment in 1970s and has expanded with its principles in the world wide, especially during and after the global financial crisis 2007-2008 which led to difficulties in many conventional banks however, global Islamic realized an asset over 1.3 trillion according to (IMF, WP/11/156). And hit 2.4 Trillian Dollars in 2017.which means about 10\% percent per year .That leads us to anticipate that the assets of Islamic banking will reach over 3.8 Trillian dollars by 2023 .

Islam is one of the religions that prohibited the use of usury and so called 'Riba' in all business practices and dealings since money is an important tool in our hands that we must employ it as a source to develop our economies. The concept of Islamic finance that the world knows today is based on an investment motivated by moral and social responsibility.

We also noticed that, it is hard to distinguish between Islamic Banking and conventional banking just by giving and inserting irrational justifications from the Islamic sharia to "justify and lend credibility to the Islamic brand name (Khan, 2010). It is not surprising that the Algerian government has launched Islamic banking as an experiment to enlarge it year by year and to encourage people and business dealers to deal with Islamic financial products ,especially that Algerian Government entered new reforms in the Algerian financial market in the last Finance Law 2018. 
We, also agree that researchers may have different results on the same topic according to the variables and even the time series or the country profile studied. In our turn, our results differ from former studies(Aysan, Disli, \& Ozturk, 2018) (Haseeb, 2018) since it determines the merits of the Islamic monetary system through attracting attention to the relative stability afforded by the interest-free system and also encourage the continued moderate and modest success of Islamic banks in Algeria to target primarily business generated from strategic partnership with domestic and regional sovereign and public sector entities. Moreover, our results also illustrate the great focus of Islamic banking on securing facilities with tangible collaterals in building business relationships. Islamic Finance is not a religious system, but it's an ethical system for all people to make money either Muslim or non-Muslim.

\section{Literature review}

Various writings on Islamic banking and finance dated to the twentieth century. The birth of Islamic banking and Islamic economics goes to the deem past where most Arabic countries were under the dominant Western systems of capitalism and communism.This part of the world suffered from colonizers who combated Islam religion sharia . At that period famous Islam thinkers worked hard to show and found Islamic socio-political and economic systems, among these Islamic thinkers ,we find,Ibn Bidis a famous Islamic thinker from Algeria, Mohamed Ali in Egypt, Mohammad Baqir Al-Sadr (1961) in his book entitled our Economy, and Sayyid Abul A'la Maududi in Economic System of Islam, 1970. During this period there were many experiments to establish Islamic houses or banks, but they did not see success for political reasons. The first Islamic bank was established Thanks to a great effort and support from the economist, Dr. Ahmed Al-Najjar who founded 'Bayt Guamr Bnak' in Egypt in 1961(Siddiqi, 2006).

Actually, there are lot of developed and developing countries which suffer from a lack of real harmony and effects between the degree of development and economic growth since poverty rate increased and the number of wealthy people increased and even doubled in many cases.

The modern definition of development represents the objectives of Islamic finance after the failure of the strategies and theories to achieve development and since 1980, the United Nations began to look for a new definitions for development and define it as a sustainable civilization process and a human right to create structural transformations and social and economic changes that allow for a steady escalation of the capacities of the society concerned and continuous improvement of the quality of life in it(Iqbal \& Molyneux, 2005).

Islamic banking is currently growing fast and Contribute in varying proportions in the economic growth either in a low or high degree and this due to the government policy and The extent of the application of Islamic banking but in both cases ,Islamic banking really represents a significant determinant(Hassan \& Bashir, 2003). The potential effects of Islamic banking on economic growth was involved with individual countries and even studied the macroeconomic stability(El-Galfy \& Khiyar, 2012) and investigated a comparative performance between conventional banking and Islamic banking.

\section{Definitions}

Islamic banking system is the financial institution which operations and activities are based on Islamic Sharia (Mohamad, Abdullah, Mohamad, \& Abidin, 2013) however, (Abdelrahman, 2015) defines Islamic banking as an institution that 
provides financial and investment services that are complaint with Sharia and from this definitions we can conduct that ,Islamic finance system compared to western conventional system is related to Islam religion rules. The principals of Islamic finance are based on three main factors which are mentioned in the Quran and are an important part of Sharia and Islamic jurisprudence. They are Riba, Gharar and Maysir, which are explained in detail below.

- Halal and haram concept : The concept of Halal means permissible and derived from the by the Islamic religion and the same deal for the concept oh haram and Haram and both represent the foundation of Islamic finance(Mukhtar \& Mohsin Butt, 2012).That halal what God and His Messenger allowed to Muslims .This term also means what is permitted, pure, permissible and clean .However, haram means what is forbidden by God and His Messenger.

- Riba : Riba is one of the most dangerous sin ad plagues of societies and all religions agreed on its prohibition._Such as giving someone borrow money to someone else and asks him to return it with an increase of $1 \%$ as interest. Riba is derived from the Quran and is unanimously accepted by all Islamic thinkers. They also divided riba to two types ,the first is called 'Riba An Nasiyah' and the second is named 'Riba Al Fadl'(Todorof, 2018).

- Gharar : is cheating in business and can be defined as the manner of hide and push push partners into risks (Asni \& Sulong, 2018) and a sort of abuse of trust . we also can distinction between two sorts of Gharar: Gharar Elfahish which is forbidden by Islamic sharia while the second is tolerated .

Table 1: the Islamic development bank history

\begin{tabular}{|l|l|l|}
\hline Chronology of Islamic banking & Country & Date \\
\hline the Mit Ghamr Savings Bank . & Egypt & In 1961 \\
\hline $\begin{array}{l}\text { the Pilgrims Saving Corporation of } \\
\text { Malaysia. }\end{array}$ & Malaysia & In 1963 \\
\hline the Islamic Development Bank opened. & $\begin{array}{l}\text { Saudi } \\
\text { Arabia }\end{array}$ & In 1975 \\
\hline $\begin{array}{l}\text { the Islamic Insurance Company (Based on } \\
\text { takaful) company }\end{array}$ & Sudan & In 1979 \\
\hline $\begin{array}{l}\text { the world's first Islamic mutual fund in } \\
\text { Indiana- usa }\end{array}$ & Usa & In 1990 \\
\hline the first tradable sukuk & Malaysia & In 1990 \\
\hline the Citi Islamic Investment Bank & Bahrain. & In 1996 \\
\hline $\begin{array}{l}\text { the Islamic Financial Services Board (IFSB) } \\
\text { was established }\end{array}$ & Malysia & In 2002 \\
\hline $\begin{array}{l}\text { the first Islamic commercial bank founded } \\
\text { outside the Muslim world }\end{array}$ & Uk & In 2004 \\
\hline
\end{tabular}

Source: https://www.dummies.com/personal-finance/investing/emerging-markets

Islamic banking has emerged modestly in the last two decades with the first bank in Egypt in 1961 and after 14 years the Islamic Development Bank opened in Saudi Arabia in 1975 then the first tradable sukuk in Malaysia IN 1990. Actually, the number of Islamic banks have registered a great growth and reached 505 Islamic banks in the world including 207 Islamic windows. 


\section{Methodology}

This study used qualitative research methods and some financial ratio because of the great inadequate data about Islamic banks in Algeria in order to analyze the performance of Islamic banking in Algeria, we have also tried to interview the Baraka manager in order to get some descriptive statistics to use them both in analyzing the positive elements and obstacles faced by Islamic banks and to prescribe financial reforms for this sector.

\section{Global Islamic finance assets growth from 2012 to 2019.}

We do agree that, Islamic banking is no longer a monopoly of Islamic countries or that believe in Islam religion since this kind of banks has spread in the word as a real financial industry and globalization has helped in its expansion,too.

We can also notice that Islamic banking assets jumped from 1.7 Trillian dollars in 2012 to 2.2 Trillian dollars by the year 2016 and hit 2.8 Trillian dollars in 2018 .

\section{Chart 1: Global Islamic Finance Industry Assets}

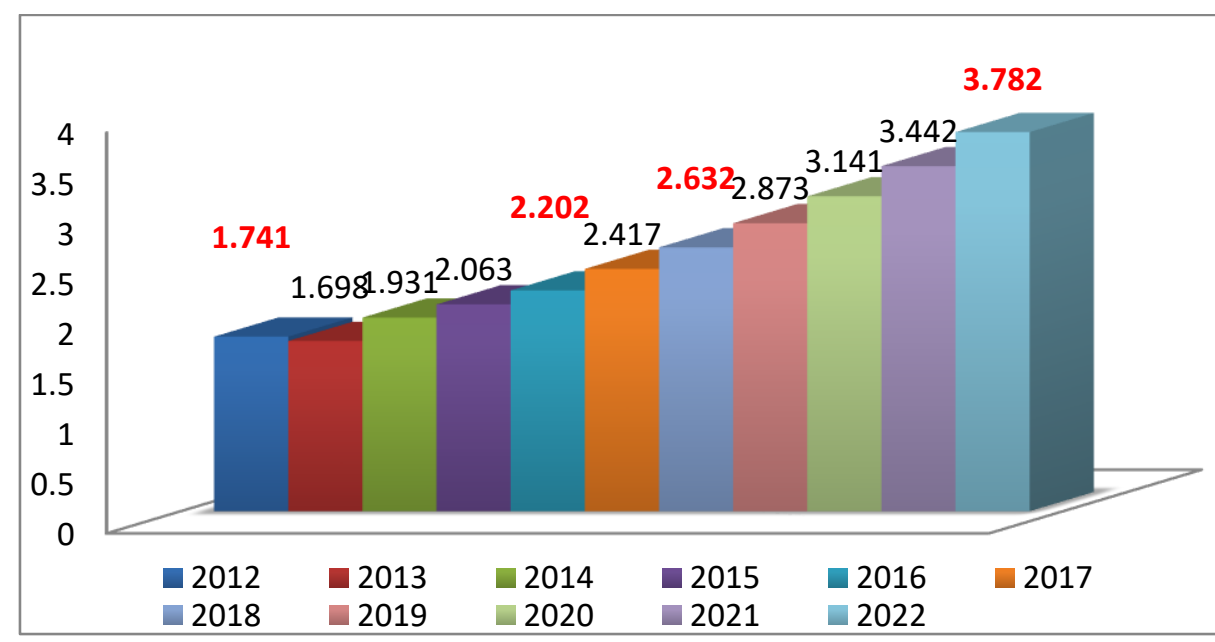

Source: Islamic Financial services Broad

During the beginning of the year 2019, the percentage of Islamic investments in the infrastructure and sukuk bonds increased significantly, as these investments witnessed a rapid development in the field of financial technology sector (Fintech) . The performance of the Islamic banking sector grew by a mere $0.9 \%$ in 2018 , compared to $4.3 \%$ in 2017. As many Islamic banks began adopting advanced electronic systems to facilitate services and increase the efficiency of Islamic banking, these banks also developed methods of innovation in the manufacture of Islamic financing tools. From the previous table, we find that the statistics indicate a possible rise to 3.1 Trillian dollars by the end of 2019 and probably may reach about 3.7 Trillian dollars in 2022 .

\section{Why Islamic banking system is growing fast ?}

From the chart below, we found that Islamic banking prohibit speculation and interest according to the Islam religion. Moreover, Islamic banking doesn't enter in any 
prohibited deals or investments like investment in alcohol sector or drugs. They avoid Toxic assets, too and prefer to invest in real and durable assets.

\section{Chart 2: Islamic banking}

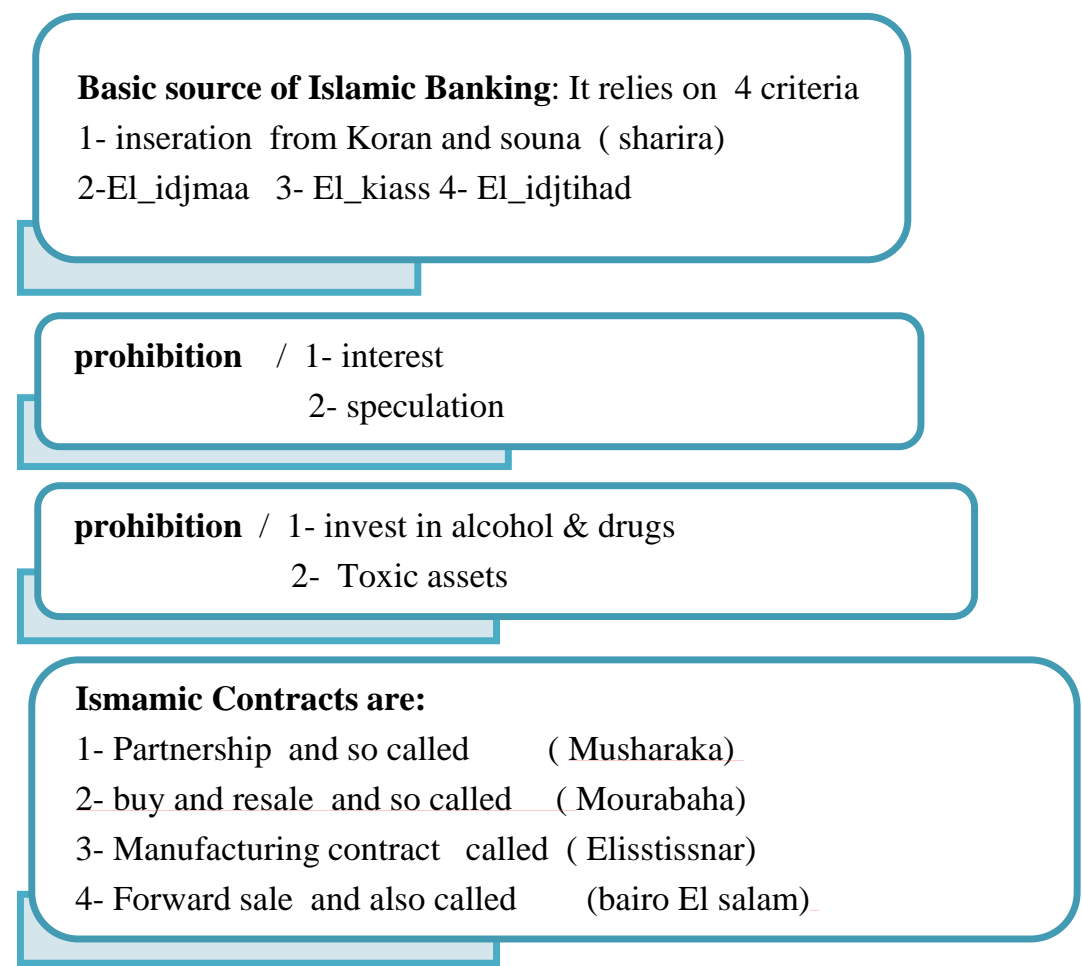

Source : Hassan, K., \& Lewis, M. (Eds.). (2009). Handbook of Islamic banking. Edward Elgar Publishing

\section{More details about Islamic banking products.}

- Musharaka : This The term refers to an Islamic product. It is also a financing participation of the bank in a venture by a company or a customer. The customer and the bank together raise the capital, usually the working capital, for the venture. In the Musharaka agreement both, the Bank and the customer share the profits and losses as per to mutually agreed proportions(Billah, 2019).

- Murabaha (Buy and resale) : Is one of the most famous sale contract based on negotiation used by the Islamic banks(Faishal \& Saleh, 2019) .It is a contract between a customer and the bank. Murabaha is not a loan given on interest but in reality it is an arrangement wherein the bank purchases goods upon request of the client, who in his turn makes deferred payments that cover the costs and at an agreed profit margin for the bank.

- Elisstissnar (Manifacturing contract): Is similar to a regular financing for working capital. All features are similar to a Murabaha except that the actual delivery of goods happen at a later date after the receipt of all due payments(Chong \& Liu, 2009).

- Bairo Elssalam (Foreword sale) : Ii is contract in which the byer and the seller agree to use the term 'bairo Elsslam' as a main condition in their contract in 
advance where they specify the goods quality, quantity, price ...ects and which may be delivered at a future date in exchange of an advance price fully paid at the time of contract. Moreover, the objects of this sale must be goods and cannot be gold, silver, or currencies based on these metals.

\section{Islam Philosophy towards economy}

Islam not only prohibits dealing in interest but also Islamic banking is an instrument for the development of an Islamic economic order. Islam makes a clear distinction between what is halal (lawful) and what is haraam (forbidden) in purs, Islam makes it obligatory on the individual to spend his wealth judiciously and not to hoard it, keep it idle, or to squander it. The economic system envisaged by Islam aims at social justice. First, Islam seeks to prevent the accumulation of wealth in a few hands to the detriment of society as a whole through its laws of inheritance.

More than 500 Islamic financial institutions operate in the world today.the number of Islamic financial institutions grew from around 85 in 1996 to 200 in 2000 and to 300 in 2008. An Islamic bank is not permitted to lend to other banks at interest. Islamic banking refers to a system of banking or banking activity that is consistent with principles of Shariah and guided by Islamic economics. Since this system of banking is grounded in Islamic principles, all the undertakings of the banks follow Islamic morals. Therefore, it could be said that financial transactions within Islamic banking are a culturally distinct form of ethical investing. For example, investments involving alcohol, gambling, pork, etc. are prohibited.

Islamic banking plays at least four important roles: it encourages lending, stimulates saving, promotes financial stability, and contributes to financing morally acceptable projects (Imam \& Kpodar, 2016) Islamic finance is considered a stable financing system that is capable of promoting growth and creating long-term employment.

According to the literature concerning the relationship between Islamic banks and economic growth, one could safely say that Islamic banking is a new financial system that must strictly comply with Islamic Sharia regulations.

\section{banking? \\ What is the difference between Islamic banking and conventional} We do agree that conventional banks are based on fully man made principles. However, Islam banking teaching says that, to make money from money is prohibited and wealth can only be generated through legitimate trade and investment. Any gains relating to this trade are shared between the person providing the capital and the person providing the expertise. As matter of fact, money itself has no intrinsic value and therefore Islam rules forbids people from profiting by lending it, without accepting a level of risk, i.e., interest (known as riba) cannot be charged.

\section{What is riba and why is it prohibited?}

In Arabic, riba literally means "excess". Simply stated, riba is interest. Any amount, big or small, over the principal in a contract of loan or debt is riba, prohibited by the Quran, regardless of whether the loan is taken for the purpose of consumption or for some production activity. Prohibition of interest is ordained in Islam in all forms and intent. This prohibition is strict, absolute, and unambiguous. It therefore means that interest is prohibited as it leads to injustices (zulm), and Islam is against all forms of injustice and exploitation and seeks an economic system that aims at securing extensive socio-economic justice. The Islamic law of prohibition of riba was 
originally not based on economic theory, but on divine authority, which considers the charging of interest as an act of injustice.

\section{The relation between Islamic Banks and the Central Bank.}

One of the most important role of Central Banks consists in supervising the activities applied on banks such as checking registers and books for the purpose of validating assets and the different operations. The central banks are involved in developing and boosting rules and setting the range of dealing with specific activities and clients.

The relation between Islamic banks and Central Banks is a key driver to increase the growth of Islamic banks through assisting them and creating the best environment which helps both the conventional banks and Islamic banks to work integration and consistency.

Therefore, Central banks have to facilitate the integration and the work of Islamic banks; they have to and support them in order to contribute positively in the sustainable development. Islamic banks need special treatment and adopt special rules to encourage them in their performance since they don't deal with Riba. Besides, special reserves, limitation on equity, voting rights, and encouraging their wide spread and also in creating new branches.

- Some states have issued special legislation for Islamic banks .

- To prevent the damage to economy that may be cause by the collapse of banks. In some states the central bank provides finance to conventional banks in the form of an interest-based debt and provides liquidity for Islamic banks as a form of Mourabaha or Moucharaka.

- The central bank can allow limited short-term temporary facilities free of interest of Islamic banks on the basis that these banks would place compensatory funds of the same amount for an equivalent duration.

\section{Islamic Banking in Algeria}

One of the available options to mobilize domestic savings for the Algerian authorities is to move towards Islamic banking which in the last decade and in many economic sectors. The Islamic products can be applied in Algerian banks as an experience to withdraw investors who prefer Islamic methods and rules such as Murabaha or the purchase of a product and resale it in the form of Murabaha according to the sharia rules far from usury deals. The purpose here is to attract citizens, both local or foreigners, to buy bonds that allow them to participate in investment projects in different sectors and without interest rate in return for an agreed profit margin in the case of profit and accept losses in the case of high risk or loss.

\section{Success of Islamic banks in Algeria depend on:}

$\checkmark$ Use of the high technologies in Islamic banks(Al-Sartawi, 2017).

$\checkmark$ The rationalization of the Algerians' point of view towards Islamic banks.

$\checkmark$ Provide a legal environment that allows the work in accordance with Islamic rules.

$\checkmark$ Opening the capital of this type of banks for public subscription by $50 \%$ and $50 \%$ of the contributions of the state sectors such as the Ministry of Religious Affairs and the major productive companies of the state.

$\checkmark \quad$ Digitization of Islamic banking through using safer and more secure technology in this sector to protect all partnerships.

$\checkmark$ Training of experts in the field of Islamic banks.

$\checkmark$ Allowing the Islamic banks to invest and share international investments.

$\checkmark$ Benefit from the experiences of leadership Islamic banks at international level. 


\section{Obstacles faced by Islamic banks in Algeria}

Before to discuss the problem faced by Islamic banks in Algeria. Let's give a short idea about one of the famous Islamic banks in Algeria so called Al Baraka Bank of Algeria is the first bank with mixed capital (public and private). It was established on May 20, 1991 with a capital of 500,000,000 DAJ, and it began practicing its activities physically during the month of September 1991.We can sum up the most important obstacles which Islamic banking face and among them Al Baraka bank in Algeria as fellow :

Hoarding cash at home: Experts and economists believe that the circulation of liquidity in Algeria outside the official channels is due to the unwillingness of the Algerian society to open the door to deal with conventional banks for fear of disobedience to God and the benefits of "usury".

The total absence of an Islamic financial market :No doubt that the existence of Islamic monetary financial market can contribute to the revitalization of Islamic transactions. Therefore, it became necessary to give the opportunity for Islamic banks to operate in accordance with Islamic rules and protect them from the unfair deals of the Central Bank(Hesse, Jobst, \& Sole, 2008).

The multiplicity and contradiction of judgments: The Islamic judgments concerning faith are largely fixed, however concerning transactions are many and multiple.

Table 2: Financial indicators of Al Baraka Group from 2014 to 2018

\begin{tabular}{|l|l|l|l|l|l|}
\hline $\begin{array}{l}\text { Financial } \\
\text { indicators }\end{array}$ & $\mathbf{2 0 1 4}$ & $\mathbf{2 0 1 5}$ & $\mathbf{2 0 1 6}$ & $\mathbf{2 0 1 7}$ & $\mathbf{2 0 1 8}$ \\
\hline $\begin{array}{l}\text { Total } \\
\text { operating } \\
\text { income }\end{array}$ & 918 & 1000 & 1074 & 999 & 1021 \\
\hline $\begin{array}{l}\text { Net income } \\
\text { to equity }\end{array}$ & 152 & 163 & 152 & 169 & 174 \\
\hline \multicolumn{5}{|c|}{ Financial position } \\
\hline Total assets & 23464 & 24618 & 23425 & 25453 & 25524 \\
\hline $\begin{array}{l}\text { Total } \\
\text { financing }\end{array}$ & 17624 & 18358 & 17465 & 19123 & 19207 \\
\hline $\begin{array}{l}\text { Total } \\
\text { customers }\end{array}$ & 19861 & 20164 & 19179 & 20670 & 20750 \\
\hline \multicolumn{5}{|c|}{ Profit rates } \\
\hline $\begin{array}{l}\text { Return on } \\
\text { average } \\
\text { equity }\end{array}$ & $\% 14$ & $\% 14$ & $\% 13$ & $\% 09$ & $\% 12$ \\
\hline $\begin{array}{l}\text { Operating } \\
\text { expenses }\end{array}$ & $\% 57$ & $\% 54$ & $\% 53$ & $\% 57$ & $\% 56$ \\
\hline \multicolumn{5}{|c|}{ Financial position rates } \\
\hline $\begin{array}{l}\text { The ratio of } \\
\text { total assets }\end{array}$ & $\% 25$ & $\% 24$ & $\% 24$ & $\% 26$ & $\% 25$ \\
\hline $\begin{array}{l}\text { The total } \\
\text { employees }\end{array}$ & 10853 & 11458 & 12644 & 12795 & 12865 \\
\hline $\begin{array}{l}\text { Total number } \\
\text { of branches }\end{array}$ & $\mathbf{5 4 9}$ & $\mathbf{5 8 6}$ & $\mathbf{6 9 7}$ & $\mathbf{6 7 5}$ & $\mathbf{6 7 9}$ \\
\hline
\end{tabular}

Source: Annual Report 2018, from : https://www.albaraka.bh/en-gb/annual-reports/ 
From the table 2 above, it is clear that the profits of Al Baraka Banking Group are increasing from 2014 to date 2016, by downloading the Total Operating Income Index, which reached US \$ 1074 million in2016, down from 2017, amounting to about \$ 999 million. However, for the net income to equity, an increase was observed throughout the study period, but it decreased in 20155 and has increased again to 174 in 2018. On other hands, the number of total customers moved from 19861 in 2014 to 20670 in 2017 however,

We also can notice that the total number of branches is growing fast from 549 to 679 and this Islamic bank employs more than 12865 in different countries.

Table 3: Evolution of Al Baraka Bank in Algeria (in millions DZD)

\begin{tabular}{|l|c|c|c|}
\hline Al Baraka Bank in Algeria & $\mathbf{2 0 1 6}$ & $\mathbf{2 0 1 7}$ & $\mathbf{2 0 1 8}$ \\
\hline Balance sheet & 210344 & 248633 & 270996 \\
\hline Own funds & 24312 & 24546 & 27429 \\
\hline Customer deposits: & 170137 & 207944 & 223995 \\
\hline Financing & 110711 & 139677 & 156460 \\
\hline Off-balance sheet & 64210 & 72108 & 61124 \\
\hline Net Banking Product & 8539 & 8669 & 11850 \\
\hline Net profit & $\mathbf{3 9 8 4}$ & $\mathbf{3 5 4 8}$ & $\mathbf{5 1 6 7}$ \\
\hline
\end{tabular}

Source :Annual report 2018.From : www.albaraka-bank.com/wp-content/uploads/2019/11/RAPPORT2018-fr.pdf

From the table 3 above, we can also notice that the balance sheet stands at 270996 million Algerian dinars at the end of 2018, recording an increase of 22363 million Algerian dinars corresponding to $+8.99 \%$ compared to 2017. The own funds reached 27,429 million Algerian dinars which means $+11.75 \%$ compared to 2017 against 24,546 million Algerian dinars, in 2017.However, Customer deposits reached 223,995 million Algerian dinars, registering an increase of 16 billion Algerian dinars corresponding to $+7.69 \%$ compared to 2017 and $+31.59 \%$ compared to 2016 .we can see obviously, that Al Baraka bank financing increased in Algeria by 16783 million Algerian dinars corresponding to $+12.02 \%$ compared to the previous year, to stand at 156.460 million Algerian dinars at the end of 2018. Finally, it seems clear that net profit knew a positive jump since It reached more than 5,167 million Algerian dinars against 3,548 million Algerian dinars at the end of 2017and 3984 million Algerian dinars in 2016, thus means an increase about 1,183 million Algerian dinars over the last three years, which means a successful 1 rate over $29.70 \%$ increase.

Recently Algeria knows a serious political reforms especially after the fall down of heads of the political and economic corruption in Algeria(Midoun, 2016) who squandered colossal sum of public money and took advantage from their political positions as ministers(Sissani \& Belkacem, 2014) and have always worked against the establishing of Islamic banks only because public banks were their easy way to finance their suspicious investment which was destructive to the local economy. Unfortunately, They have only abused from the use of public money estimated at 200 billion dollars into conventional banks. And due to the suffocating financial crisis in Algeria since 2008, the policy makers found that the solution was to open two of the Islamic windows as an experiment.

Today, after the fall down of the heads of corruption, and the issuance of the new finance law, the Islamic banks became an alternative solution(Platonova, Asutay, Dixon, \& Mohammad, 2018) and an imposed reality not only in Algeria but in the whole world as well. Nowadays, lot of countries are racing to open Islamic banks to 
attract huge capitals, especially from Gulf countries and created a hot competition between countries like France, Britain and even Switzerland to absorb Arab capitals.

\section{Conclusion}

There is, however, a misconception that Islamic finance is for Muslims only. This is far from the truth. Muslims can safely invest in industries such as telecommunications, technology, the health sector and temp agencies. There is no requirement that firms whose shares are bought are of a special Islamic character.

It is time that Muslims go ahead and invest their stagnant funds into the Islamic banks projects, which apply the Islamic religion, including moderation and benevolent disputes through Islamic ethics. In this research, we tried to talk about Islamic banks as a model that permits to gather and accumulate capitals in order to create Islamic financial market. In Algeria, it seems clear that the Government budget suffer from a serious deficit caused by the lower price of the barrel, as matter of fact moving quickly to develop Islamic finance with Sharia compliant may solve a little bite the critical situation. The government allowed banks to start offering Islamic products by December; however the other state banks will receive the greenlight by the end of 2018. This decision is estimated to attract at least 23.97 billion US\$. The Financial Bill 2018 will accommodate Sukuk. The Algerian Public Treasury intends to tap the Islamic capital market several times until 2022 with the first issuance planned for 2018.

Unfortunately, Islamic finance in Algeria has remained relatively undeveloped due to historical and political reasons, and because of political corruption and financial instability as main reason. Only two Islamic banks, the first is Al Baraka bank and Gulf Bank Algeria are currently allowed to offer Islamic products.

Finally, the Algerian authorities and policy makers can take advantages from the Islamic banks as an economic to develop the national economy and diversify its incomes instead of relying on the oil prices.

\section{References}

Abdelrahman, A. Y. (2015). Does Islamic banking help in economic development of Muslim countries?

Al-Sartawi, A. (2017). The effect of the electronic financial reporting on the market value added of the islamic banks in gulf cooperation council countries. Paper presented at the 8th Global Islamic Marketing Conference.

Asni, F., \& Sulong, J. (2018). Hybrid Contracts according to Islamic Perspective. International Journal of Academic Research in Business and Social Sciences, $8(5), 453-458$.

Aysan, A. F., Disli, M., \& Ozturk, H. (2018). Bank lending channel in a dual banking system: why are Islamic banks so responsive? The World Economy, 41(3), 674-698.

Billah, M. M. S. (2019). Musharakah Venture Capital Modern Islamic Investment Management (pp. 83-89): Springer.

Chong, B. S., \& Liu, M.-H. (2009). Islamic banking: interest-free or interest-based? Pacific-Basin finance journal, 17(1), 125-144.

Faishal, M., \& Saleh, C. (2019). Development of Identical Delivery Quantity Model in Inventory Management with Delayed Payments based on Bank Interest Rates and Murabaha Systems. Paper presented at the IOP Conference Series: Materials Science and Engineering. 
Haseeb, M. (2018). Emerging issues in islamic banking \& finance: Challenges and Solutions. Academy of Accounting and Financial Studies Journal, 22, 1-5.

Hesse, H., Jobst, A. A., \& Sole, J. (2008). Trends and challenges in Islamic finance. World Economics, 9(2), 175-193.

Midoun, S. (2016). The algerian economy governed by black corruption: an empirical study from 2002 to 2015. Studies and scientific researches. Economics edition(24).

Mohamad, M. T., Abdullah, M. Y., Mohamad, M. A., \& Abidin, U. Z. A.-A. Z. (2013). The historical development of modern Islamic banking: A study in South-east Asia countries. African Journal of Business Management, 1(1), 114.

Mukhtar, A., \& Mohsin Butt, M. (2012). Intention to choose Halal products: the role of religiosity. Journal of Islamic Marketing, 3(2), 108-120.

Platonova, E., Asutay, M., Dixon, R., \& Mohammad, S. (2018). The impact of corporate social responsibility disclosure on financial performance: Evidence from the GCC Islamic banking sector. Journal of Business Ethics, 151(2), 451-471.

Sissani, M., \& Belkacem, Z. (2014). The Effect of Political Risk on Foreign Direct Investment: The Case of Algeria. Hyperion Economic Journal, 2(3), 29-35.

Todorof, M. (2018). Shariah-compliant fintech in the banking industry. Paper presented at the ERA Forum. 